\title{
Pemanfaatan Teknologi Informasi dan Komunikasi dalam Pembelajaran Daring
}

\author{
${ }^{1}$ Erna Chotidjah Suhatmi, ${ }^{2}$ Retna Dewi Lestari, \\ ${ }^{3}$ Sopingi \\ Universitas Duta \\ Bangsa Surakarta \\ Indonesia \\ erna_chotidjah@udb.ac \\ .id
}

\begin{abstract}
Tujuan dari penelitian ini adalah untuk mengetahui peran pemanfaatan Teknologi Informasi dan Komunikasi oleh mahasiswa dalam menunjang pembelajaran daring. Penentuan responden secara purposive dengan ketentuan merupakan mahasiswa aktif Universitas Duta Bangsa Surakarta. Populasi dari penelitian adalah seluruh mahasiswa Universitas Duta Bangsa Surakarta yaitu sejumlah 3.896 mahasiswa. Sampel dari penelitian ini adalah 160 mahasiswa Universitas Duta Bangsa Surakarta. Penggunaan data dalam penelitian ini adalah menggunakan data primer, data primer didapatkan melalui wawancara dengan responden. Hasil penelitian menunjukkan penggunaan TIK dalam pembelajaran daring telah diterapkan di Universitas Duta Bangsa Surakarta dibuktikan dengan respon 120 (75\%) mahasiswa "sangat setuju" dan "setuju" dengan pernyataan penggunaan elearning dan aplikasi komputer lainnya dalam pembelajaran daring. Pemanfaatan TIK oleh mahasiswa dalam pembelajaran daring membantu mahasiswa dalam menyelesaikan tugas tepat waktu, dan menambah kemampuan mahasiswa dalam mengoperasikan aplikasi-aplikasi tesebut. Ditunjukan dari respon mahasiswa terhadap pemanfaatan TIK dalam membantu menyelesaikan tugas sebanyak 142 mahasiswa $(88,75 \%)$ menyatakan respon "sangat setuju" dan "setuju". Pemanfaatan TIK dalam menunjang pembelajaran daring memiliki faktor penghambat utama diantaranya adalah masalah jaringan internet yang sering terjadi dan masih adanya mahasiswa ataupun dosen yang belum menguasai penggunaan TIK dalam pembelajaran daring. Faktor penunjang dalam pemanfataan TIK dalam pembelajaran daring adalah fasilitas kuota, fasilitas kepemilikan laptop/PC, handphone android dan support system dari orang tua. Dari hasil penelitian tersebut diperlukan solusi untuk mengatasi faktor penghambat dalam pemanfaatan TIK dalam menunjan pembelajaran diantaranya, perlu adanya fasilitas tersedianya alat penangkap sinyal dan perlu adanya peningkatan pelatihan baik terhadap mahasiswa dan dosen yang kurang memahami tata kerja penggunaan TIK dalam pembelajaran daring.
\end{abstract}

\section{Keywords: TIK, Pembelajaran Daring, Mahasiswa, Pandemi Covid 19}

\section{PENDAHULUAN}

Virus corona (Covid 19) yang masuk ke Indonesia mulai awal tahun 2020, memberikan dampak yang luas terhadap perekonomian, kehidupan sosial bermasyarakat dan salah satunya juga mempengaruhi dunia pendidikan. Selama masa pandemi ini, siswa dan mahasiswa diwajibkan untuk belajar dirumah atau pertemuan pembelajaran secara daring untuk menghindari penyebaran virus corona. Adanya pembelajaran daring ini tentunya akan mengubah metode pembelajaran yang selama ini dijalankan, yang awalnya tatap muka secara langsung berubah menjadi pertemuan secara online dengan memanfaatkan teknologi yang ada. Berdasarkan data Stastitik Pendidikan Tahun 2020 penggunaan Teknologi Informasi dan Komunikasi 
mahasiswa selama kurun waktu tahun 2016-2020

meningkat sesuai dengan tabel 1.

Menurut BPS (2020) Dalam bidang pendidikan, teknologi memiliki peran penting sebagai media penunjang sistem kurikulum sekolah dan diharapkan dapat memacu dan meningkatkan kualitas pendidikan. Terlebih di masa pandemi saat ini, pemerintah mengeluarkan kebijakan School From Home (SFH) dimana kegiatan pembelajaran dialihkan dari pembelajaran tatap muka menjadi daring karena situasi yang tidak memungkinkan untuk melaksanakan kegiatan secara langsung di sekolah. Tidak hanya kegiatan belajar mengajar, kegiatan ekstrakurikuler dan acara seremonial seperti kelulusan dan orientasi siswa juga beralih menjadi daring. Semua kegiatan tersebut tentunya dapat dilaksanakan dengan memanfaatkan teknologi yang semakin berkembang. Oleh karena itu, hal ini menuntut siswa di semua jenjang pendidikan untuk melek teknologi serta memanfaatkannya.

Dengan adanya kebijakan pemerintah terkait SFH maka baik siswa maupun mahasiswa mampu mengoperasikan berbagai aplikasi yang mendukung pembelajaran. Berbagai aplikasi tersebut juga memudahkan mahasiswa dalam mengerjakan tugas di masa SFH ini. Software atau perangkat lunak yang seringkali digunakan oleh mahasiswa dalammengerjakan tugas adalah Microsoft Word, Microsoft Excel, Microsoft Powerpoint, Coreldraw. Selain itu penggunaan aplikasi konferensi seperti google meet, zoom meeting, google classroom, elearning juga membantu pembelajaraan secara daring. Adanya kewajiban pertemuan perkuliahan secara daring tentunya akan mempengaruhi kemampuan mahasiswa dalam mempengoperasikan software tersebut. Maka perlu ada penelitian terkait penggunaan teknologi informasi dan komunikasi dalam menunjang pembelajaran daring. Tujuan dari penelitian ini adalah untuk mengetahui peran pemanfaatan Teknologi Informasi dan Komunikasi oleh mahasiswa dalam menunjang pembelajaran daring.

\begin{tabular}{|l|l|l|l|}
\hline \multirow{2}{*}{ Jenis Akses TIK } & \multicolumn{4}{|c|}{$\begin{array}{l}\text { Persentase A Akses } \\
\text { TIK }\end{array}$} \\
\cline { 2 - 4 } & $\mathbf{2 0 1 8}$ & $\mathbf{2 0 1 9}$ & $\mathbf{2 0 2 0}$ \\
\hline $\begin{array}{l}\text { Menggunaka } \\
\text { nKomputer }\end{array}$ & 63,76 & 66,14 & 68,15 \\
\hline $\begin{array}{l}\text { Menggunakan } \\
\text { Internet }\end{array}$ & 94,41 & 66,14 & 68,15 \\
\hline
\end{tabular}

Sumber: Statistik Pendidikan 2020(BPS, diolah)

\section{STUDI LITERATUR}

\subsection{Pemanfaatan Teknologi Informasi danKomunikasi dalam Pembelajaran Daring}

Menurut Salsabila et al, (2020) teknologi berperan sebagai media dalam melakukan interaksi antara pendidik dan peserta didik dalam pelaksanaan pembelajaran daring. Selain itu teknologi juga berperan dalam memfasilitasi pendidik untuk menyampaikan materi pembelajaran sehingga pembelajaran tetap berlangsung meskipun tidak dilakukan secara tatap muka langsung. Dalam pelaksanaan pembelajaran daring tentunya terdapat hambatan yang menjadi tantangan tersendiri bagi para pelaku pendidikan, yang berkaitan dengan budaya akademik, meliputi nilai, sikap,

pengetahuan, keterampilan, serta kesiapan sarana dan prasarana terkait teknologi. Sedangkan menurut Fitriani (2020) pemanfaatan teknologi informasi memiliki peranan yang sangat penting dalam pelaksanaan pembelajaran jarak jauh pada Universitas Bina Sarana Informatika ditengah pandemi virus corona covid19, proses pembelajaran bisa berjalan dengan baik dengan adanya teknologi informasi yang sudah berkembang pesat saat ini diantaranya elearning, google class, whatsapp, zoom serta media infromasi lainnya serta jaringan internet yang dapat menghubungkan dosen dan mahasiswa sehingga proses belajar mengajar dapat berjalan dengan baik sebagaimana mestinya meskipun ditengah pandemi virus corona covid-19. Sedangkan menurut Tekege (2017) dimanfaatkannya teknologi sebagai media pembelajaran dalam proses belajar 
mengajar, dapat mempermudah cara pengajar dalam berkomunikasi dan berinteraksidengan para siswa baik di dalam kelas maupun di luar kelas. Kebutuhan akan teknologi dalam ranah pendidikan bukanlah hal yang

baru, pemanfaatan teknologi untuk membentuk pembelajar yang kondusif dan inovatif. Pemanfaatan tersebut terbukti berperan besar dalam kelancaran proses belajar.

\subsection{Efektivitas Pembelajaraan Daring}

Menurut Damayanthi (2020) pembelajaran daring yang dilaksanakan memang cukup dapat menggantikan pembelajaran tatap muka, namun apabila dilihat dari efektivitas, pembelajaran daring belum mampu membuat tujuan pembelajarantercapai. Ketidaksiapan mahasiswa dan dosen baik dari sisi kemampuan menggunakan teknologimaupun ketersediaan sarana pembelajaran yang memadai, koneksi jaringan internet yang buruk di tempat tinggal, biaya, dan belum mampunya mahasiswa serta dosen beradaptasi dengan metode pembelajaran yang baru untuk dapat meghadirkan kondisi kelas yang kondusif secara virtual menjadi faktor yang membuat pembelajaran daring belum efektif dilaksanakan. Hal inilah yang menjadi alasan mereka untuk lebih memilih pembelajaran tatap muka kembali diterapkan apabila pandemi COVID- 19 berakhir.

Sedangkan menurut (Fetra Bonita Sari, Risda Amini, 2020) pembelajaran daring kurang efektif karena dari hasil penelitian menunjukan bahwa $79 \%$ mahasiswa menginginkan pembelajaran secara tatap muka, sedangkan hanya $1 \%$ saja mahasiswa yang

menginginkan pembelajaran daring. Hal ini disebabkan oleh rasa bosan secara berulang sehingga mencapai titik jenuh. Selain itu materi yang mampu di serap mahasiswa kurang dari setengahnya, ditambah dengan kemampuan dosen dan mahasiswa dalam menggunakan internet yang masih rendah. Dengan demikian pembelajaran daring dirasa cukup efektif manakala hanya dilakukan sewaktu-waktu tidak terus menerus selama 1 semester. Hal ini senada dengan penelitian Surjono dan Herman Dwi (2010) yang menyatakan bahwa pemanfaatan TIK dapat mendukung peningkatan kualitas pembelajaran dan kualitas pelayanan administrasi akademik.

\section{METODE}

Metode penelitian yang digunakan dalam kajian ini adalah dengan menggunakan metode kuantitatif melalui wawancara dengan responden. Penentuan responden secara purposive dengan ketentuan merupakan mahasiswa aktif Universitas Duta Bangsa Surakarta. Populasi dari penelitian adalah seluruh mahasiswa Universitas Duta Bangsa Surakarta yaitu sejumlah 3.896 mahasiswa. Sampel dari penelitian ini adalah 160 mahasiswa Universitas Duta Bangsa Surakarta, 160 mahasiswa tersebut merupakan mahasiswa yang berasal dari empat fakultas yaitu Fakultas Ilmu Kesehatan, Fakultas Ilmu Komputer, Fakultas Hukum dan Bisnis, serta Fakultas Sains dan Teknologi. Sehingga masing- masing fakultas terdapat 40 sampel yang mewakili dari setiap populasi mahasiswa di Universitas Duta Bangsa Surakarta. Penggunaan data dalam penelitian ini adalah menggunakan data primer, data primer didapatkan melalui wawancara dengan responden. Wawancara responden dengan menggunakan skala likert melalui Google Formulir, pertanyaan yang diberikan adalah 12 pertanyaan terkait pemanfaatan teknologi informasi dan komunikasi dalammenunjang pembelajaraan daring. Indikator skala likert ada lima pernyataan yaitu Sangat Setuju (SS) dengan nilai skor 5, Setuju (S) dengan nilai skor 4, Netral (N) dengan skor 3, Tidak Setuju (TS) dengan skor 2, dan Sangat Tidak Setuju (STS) dengan skor nilai 1. Analisis data yang digunakan adalah analisis data secara kuantitatif mengolah data dengan Microsoft excel.

\section{HASIL dan PEMBAHASAN}

\section{1 Identitas Responden}

Identitas responden yang diteliti dalam kajian ini adalah terkait dengan umur responden dan jenis kelamin responden. Jenis kelamin responden yaitu 160 mahasiswa Universitas Duta Bangsa Surakarta disajikan pada Gambar 1. Pada gambar 1 dapat diketahui bahwa jumlah responden yang berjenis kelamin laki-laki adalah 46 mahasiswa dengan persentase sebesar $28.75 \%$ dan terdapat 114 responden yang berjenis kelamin perempuan denganpersentase sebesar $71.25 \%$. 
Berdasarkan gambar 2, responden dalam penelitian ini dibagi menjadi lima kelompok umur. Kelompok pertama rentang usia dari 18-22 tahun berjumlah 140 responden dengan persentase sebesar

87,50\%. Kelompok kedua rentang usia dari 23 tahun sampai 27 tahun sebanyak 12 responden dengan persentase sebesar 7,5\%. Kelompok ketiga, rentang usia dari umur 28 tahun sampai 32 tahun sebanyak 1

responden dengan persentase sebesar 0,63\%. Kelompok keempat, rentang usia dari umur 33 tahun sampai 37 tahun dengan persentase sebesar 2,5\%, dan kelompok kelima rentang usia dari umur 38 tahun sampai 41 tahun sebanyak 3 respondendengan persentase sebesae 1,88\%. Perbedaanrentang usia ini disebabkan oleh responden merupakan mahasiswa baik dari kelas S1 Reguler maupun S1 non regular kelas transfer ataupun kelas karyawan.
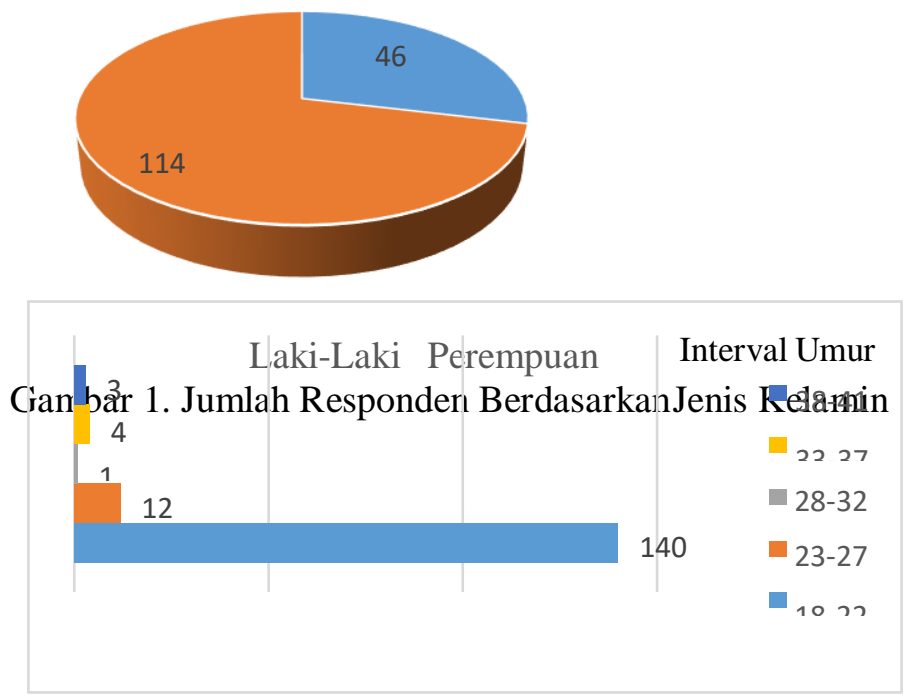

Gambar 2. Jumlah Responden Berdasarkan Umur

\subsection{Persepsi Responden TerhadapPelaksanaan Pembelajaran Daring}

Persepsi responden terhadap pelaksanaan pembelajaran daring di Universitas Duta Bangsa Surakarta diukur melalui empat pertanyaan dalamkuesioner dengan skala likert. Empat pertanyaan tersebut adalah sebagai berikut:

1) Pembelajaraan daring selalu menggunakan mediaelearning dalam pelaksanaannya. (Q1)

2) Selain menggunakan media elearning dosen, pada setiap pertemuan selalu menggunakan media komunikasi lainnya seperti google meetdan zoom dalam pembelajaraan. (Q2)

3) Penggunaan media pembelajaraan daring seperti elearning, google meet, dan zoom meeting sangat membantu memahami materi perkuliahan.(Q3)

4) Saya mahir mengoperasikan dan mengenal dengan baik tata cara penggunaan media pembelajaraan tersebut seperti elearning, google meet, dan zoom meeting. (Q4).

Hasil penelitian mengenai persepsi mahasiswa Universitas Duta Bangsa Surakarta mengenai pelaksanaan pembelajaran daring dapat dilihat pada tabel 2. Berdasarkan tabel 2 dapat diketahui bahwa persepsi mahasiswa terhadap penggunaan elearning dalam pembelajaraan daring tidak sepenuhnya $100 \%$, ditunjukkan persentase skor nilai setuju sebesar 46,3\%. Hal ini mengindikasikan bahwa tidak semua dosen memanfaatkan elearning dalam pembelajarannya. Begitu pula dengan penggunaan media komunikasi lainnya seperti zoom meeting ataupun google meet, ditunjukan nilai skor setuju lebih besar daripada nilai skor sangat setuju yaitu sebesar $45 \%$. Hal ini disebabkan oleh beberapa faktor diantaranya adalah masih adanya dosen yang belum menguasai pengunaan elearning dan aplikasi meeting seperti google meet dan zoom meeting oleh karena itu diperlukan adanya pelatihan bagi dosen atau tenaga pengajar. 
Adanya penjelasan materi menggunakan TIK seperti google meet dan zoom meeting membantu mahasiswa dalam memahami materi yang dijelaskan oleh dosen, hal ini terbukti dari tingkat skor sangat setuju sebesar 35,6\% lebih banyak dari tingkat skor pernyataan setuju. Hasil penelitian ini memberikan

rekomendasi bagi dosen Universitas Duta Bangsa Surakarta bahwa penggunaan google meet dan zoom meeting selain pengunaan elearning dapat membantu mahasiswa dalam memahami materi. Pertanyaan keenam mengenai kemampuan mahasiswa dalam menggunakan elearning, zoom meeting, dan google meet dalam menunjang

pembelajaran direspon setuju oleh mahasiswa dengan persentase sebesar 53,1. Hal ini menunjukkan masih ada beberapa mahasiswa yang belum mahir mengoperasikan media elearning, zoom meeting dan google meet dalam pembelajaraan daring.

Tabel 2. Penggunaan TIK dalam PembelajaranDaring

\begin{tabular}{|c|c|c|c|c|c|c|}
\hline \multirow{2}{*}{$\mathbf{Q}$} & \multicolumn{5}{|c|}{ Jumlah Persepsi Responden } & \multirow{2}{*}{$\begin{array}{c}\text { Jum } \\
\text { lah }\end{array}$} \\
\hline & SS & $\mathbf{S}$ & $\mathbf{N}$ & TS & STS & \\
\hline Q1 & 46 & 74 & 24 & 13 & 3 & 160 \\
\hline$\%$ & 28,8 & 46,3 & 15 & 8,1 & 1,9 & $\begin{array}{c}100 \\
\%\end{array}$ \\
\hline Q2 & 64 & 72 & 20 & 4 & 0 & 160 \\
\hline$\%$ & 40 & 45 & 12,5 & 2,5 & 0 & $\begin{array}{c}100 \\
\%\end{array}$ \\
\hline Q3 & 57 & 54 & 33 & 9 & 7 & 160 \\
\hline$\%$ & 35,6 & 33,8 & 20,6 & 5,6 & 4,4 & $\begin{array}{c}100 \\
\%\end{array}$ \\
\hline $\mathrm{Q} 4$ & 45 & 85 & 26 & 4 & 0 & 160 \\
\hline$\%$ & 28,1 & 53,1 & 16,3 & 2,5 & 0 & $\begin{array}{c}100 \\
\%\end{array}$ \\
\hline
\end{tabular}

Sumber: Data Primer (diolah)

\subsection{Persepsi Penggunaan TIK/Aplikasi Komputer dalam Menunjang Pembelajaran Daring}

Persepsi mahasiswa mengenai penggunaan aplikasi komputer dalam menunjang pembelajaran

diperoleh melalui empat pertanyaan dalam skala likert. Pertanyan tersebut adalah:

1) Dosen sering memberikan tugas yang berkaitan dengan penggunaan aplikasi komputer seperti membuat makalah, presentasi, penggunaansoftware dan lainnya. (Q5)

2) Anda sering memanfaatkan aplikasi komputer seperti microsoft word, excel, dan powerpoint, aplikasi scanner dan aplikasi lainnya dalam mengerjakan tugas yang diberikan. (Q6)

3) Aplikasi komputer seperti Ms word, Ms Excel, Ms Powerpoint, dan aplikasi lainnya membantu anda dalam menyelesaikan tugas secara tepatwaktu. (Q7)

4) Anda mahir menggunakan aplikasi untuk menunjang pengerjaan tugas tersebut sepert Ms word, excel, powerpoint, scanner, dan aplikasi lainnya (Q8)

Hasil penelitian respon pertanyaan kelima sampai kedelapan dapat dilihat pada tabel 3. Pertanyaan kelima yaitu pertanyaan mengenai seberapa sering dosen memberikan tugas yang berkaitan dengan penggunaan aplikasi komputer, direspon oleh mahasiwa dengan pernyataan "setuju" sebanyak 51,9\%. Hal ini menunjukkan bahwa sudah 
banyak dosen yang memberikan tugas terkait penggunaan aplikasi komputer diantaranya tugas makalah yang menggunakan Ms.word, presentasi dengan menggunakan Ms.powerpoint. Namun ada juga dosen yang belum memberikan tugas terkait dengan penggunaan aplikasi komputer terbukti dengan persepsi mahasiswa dengan memberikan pernyaaan sangat tidak setuju sebanyak 3 mahasiswa. Pertanyaan keenam mengenai seringnya mahasiswa memanfaatkan aplikasi komputer dalam mengerjakan tugasnya, menghasilkan pernyataan setuju sebesar $48,1 \%$ dan pernyataan sangat tidak setuju sebesar $0 \%$. Hal ini berarti bahwa sebagian besar mahasiswa telah menggunakan aplikasikomputer dalam pengerjaan tugasnya.

Pertanyaan ketujuh dan kedelapan terkait dengan aplikasi komputer dapat membantu menyelesaikan tugas dan tingkat kemahiran mahasiswa dalam mengoperasikan aplikasi tersebut. Hasil penelitian menunjukkan bahwa penggunaan aplikasi komputer membantu mahasiswa dalam menyelesaiakn tugas

tepat waktu direspon dengan pernyataan sangat setuju oleh 73 mahasiswa. Kemampuan dan kemahiran mahasiswa dalam menggunakan aplikasi komputer dalam menunjang pembelajaran daring direspon dengan pernyataan setuju sebanyak 86 orang dan respon sangat tidak setuju hanya 1 mahasiswa. Hasil ini menunjukkan bahwa penggunaan aplikasi komputer sangat penting dalam menunjang pembelajaran daring. Aplikasi komputer yang utama yang digunakan mahasiswa antara lain adalah Ms. Word, Ms. Excel, Ms. PPT dan Scanner.

Tabel 3. Penggunaan Aplikasi Komputer dalamMenunjang Pembelajaran Daring

\begin{tabular}{|c|c|c|c|c|c|c|}
\hline \multirow{2}{*}{$\mathbf{Q}$} & \multicolumn{5}{|c|}{ Jumlah Persepsi Responden } & \multirow{2}{*}{$\begin{array}{r}\text { Jum } \\
\text { lah }\end{array}$} \\
\hline & SS & $\mathbf{S}$ & $\mathbf{N}$ & TS & STS & \\
\hline Q5 & 51 & 83 & 18 & 5 & 3 & 160 \\
\hline$\%$ & 31,9 & 51,9 & 11,3 & 3,1 & 1,9 & $\begin{array}{c}100 \\
\%\end{array}$ \\
\hline Q6 & 65 & 77 & 17 & 1 & 0 & 160 \\
\hline$\%$ & 40,6 & 48,1 & 10,6 & 0,6 & 0 & $\begin{array}{c}100 \\
\%\end{array}$ \\
\hline Q7 & 73 & 70 & 15 & 2 & 0 & 160 \\
\hline$\%$ & 45,6 & 43,8 & 9,4 & 1,3 & 0 & $\begin{array}{c}100 \\
\%\end{array}$ \\
\hline Q8 & 45 & 86 & 25 & 3 & 1 & 160 \\
\hline$\%$ & 28,1 & 53,8 & 15,6 & 1,9 & 0,6 & $\begin{array}{c}100 \\
\%\end{array}$ \\
\hline
\end{tabular}

Sumber: Data Primer (diolah)

\subsection{Faktor Pendukung dan PenghambatPenggunaan TIK/Aplikasi Komputer dalam Menunjang Pembelajaran Daring}

Terdapat empat pertanyaan mengenai faktor pendukung dan penghambat penggunaan TIK dalam menunjang pembelajaran daring, pertanyaan tersebut adalah sebagai berikut:

1) Fasilitas Pendukung pembelajaraan daring telah kalian miliki seperti handphone android, laptop/PC, dan lainnya. (Q9).

2) Masalah jaringan internet menjadi kendala utama dalam penggunaan teknologi informasi dan teknologi dalam pembelajaraan daring. (Q10).

3) Mahasiswa dan dosen mengerti penggunaan dan tata kerja media teknologi dan informasi dalam pembelajaraan daring. (Q11).

4) Support System orang tua dan keluarga saat pembelajaraan daring menggunakan media komunikasi dan aplikasi komputer sudah sangat baik. (Q12)

Hasil penelitian terkait faktor pendukungdan penghambat penggunaan TIK dalam menunjang pembelajaran daring dapat dilihat pada tabel 4.Berdasarkan tabel 4. Faktor pendukung pembelajaraan daring diantaranya tersedianyafasilitas handphone andoid, laptop/PC yang dimiliki mahasiswa hanya 59 mahasiswa yang meresponsangat setuju. Sedangkan sebesar 6 mahasiswa merespon pernyataan tesebut dengan tidak setuju,hal ini menunjukkan masih ada mahasiswa yangtidak memiliki fasilitas pendukung pembelajaran.Faktor pendukung yang lainnya adalah supportsystem di 
orang tua dan kelarga saat pembelajarandaring menggunakan media komunikasi dan aplikasikompute sudah sangat baik, pernyataan ini diresponsetuju oleh 71 mahasiswa atau dengan tingkatpersentase sebesar 44,4\%. Hal ini berarti masih adamahasiswa yang menganggap orang tua atauanggota

keluarga dianggap belum mendukungpembelajaraan daing dengan penggunaan TIK. Faktor penghambat yang utama yang dialami mahasiswa adalah masalah jaingan internet yang direspon oleh 107 mahasiswa dengan sangat setuju atau dengan tingkat persentase sebesar 66,9\%. Hal ini mengindikasikan bahwa walaupun penggunaan TIK dapat menunjang pembelajaraan secara daring namun kendala sinyal akan tetap ada, sehingga diperlukan solusi jangka panjang untuk permasalahan ini. Solusi yang dapat digunakan diantaranya penggunaan alat penangkap sinyal intenet atau jaringan internet. Faktor penghambat lainnya adalah kemampuan mahasiswa dan dosen dalam penggunaan teknologi informasi dan komunikasi dirasa masih kurang, ditunjukkan dengan hasil penelitian respon dari mahasiswa terhadap pernyataan kesebelas sebanyak 86 mahasiswa setuju atau sebesar $53,8 \%$. Sehingga diperlukan pelatihan terkait penggunaan TIK dalam menunjang pembelajaran daring.

Hal ini senada dengan penelitian Keguruan \& Sukabumi (2020) kendala yang dihadapi guru dan orang tua siswa pada proses pembelajaran daring ini ialah signal yang kurang baik menghambat proses pembelajaran daring, biaya kuota yang semakin banyak, minat belajar anak yang menurun, serta waktu untuk menemani anak terbatas karena orang tua harus bekerja di waktu yang bersamaan. (Adisel, Gawdy, 2020) menyatakan kendala pemanfaatan TIK pada pembelajaran daring salah satunya belum meratanya infrastruktur yang mendukung penerapan teknologi ini dibidang pendidikan dan ketidaksiapan sumber daya manusia untuk memanfaatkan teknologi informasi dan komunikasi dalam proses pembelajaran.

Tabel 4. Faktor Pendukung dan Penghambat Penggunaan Aplikasi Komputer dalam Menunjang Pembelajaran Daring

\begin{tabular}{|c|c|c|c|c|c|c|}
\hline \multirow[t]{2}{*}{$\mathbf{Q}$} & \multicolumn{5}{|c|}{ Jumlah Persepsi Responden } & \multirow{2}{*}{$\begin{array}{l}\text { Jum } \\
\text { lah }\end{array}$} \\
\hline & SS & $\mathbf{S}$ & $\mathbf{N}$ & TS & STS & \\
\hline Q9 & 59 & 69 & 26 & 6 & 0 & 160 \\
\hline$\%$ & 36,9 & 43,1 & 16,3 & 3,8 & 0 & $\begin{array}{c}100 \\
\%\end{array}$ \\
\hline Q10 & 107 & 35 & 14 & 1 & 3 & 160 \\
\hline$\%$ & 66,9 & 21,9 & 8,8 & 0,6 & 1,9 & $\begin{array}{c}100 \\
\%\end{array}$ \\
\hline Q11 & 46 & 86 & 26 & 2 & 0 & 160 \\
\hline$\%$ & 28,8 & 53,8 & 16,3 & 1,3 & 0 & $\begin{array}{c}100 \\
\%\end{array}$ \\
\hline Q12 & 49 & 71 & 32 & 5 & 3 & 160 \\
\hline$\%$ & 30,6 & 44,4 & 20 & 3,1 & 1,9 & $\begin{array}{c}100 \\
\%\end{array}$ \\
\hline
\end{tabular}

Sumber: Data Primer (diolah)

\section{KESIMPULAN}

Berdasarkan hasil penelitian yang telah dilakukan dapat disimpulkan bahwa:

1) Penggunaan TIK dalam pembelajaran daring telah diterapkan di Universitas Duta Bangsa Surakarta dibuktikan dengan respon 120 (75\%) mahasiswa "sangat setuju" dan "setuju" dengan pernyataan penggunaan elearning dan aplikasi komputer lainnya dalam pembelajaran daring.

2) Pemanfaatan TIK oleh mahasiswa dalam pembelajaran daring membantu mahasiswa dalam menyelesaikan tugas tepat waktu, dan menambah kemampuan mahasiswa dalam mengoperasikan aplikasi-aplikasi tesebut.

Ditunjukan dari respon mahasiswa terhadap pemanfaatan TIK dalam membantu menyelesaikan tugas sebanyak 142 mahasiswa $(88,75 \%)$ menyatakan respon "sangat setuju" dan "setuju". 
3) Pemanfaatan TIK dalam menunjang pembelajaran daring memiliki faktor penghambat utama diantaranya adalah masalah jaringan internet yang sering terjadi dan masih adanya mahasiswa ataupun dosen yang belum menguasai penggunaan TIK dalam pembelajaran daring. Faktor penunjang dalam pemanfataan TIK dalam pembelajaran daring adalah fasilitas kuota, fasilitas kepemilikanlaptop/PC, handphone android dan support system dari orang tua.

4) Dari hasil penelitian tersebut diperlukan solusi untuk mengatasi faktor penghambat dalam pemanfaatan TIK dalam menunjan pembelajaran diantaranya adalah perlu adanya fasilitas tersedianya alat penangkap sinyal dan perlu adanya peningkatan pelatihan baik terhadap mahasiswa dan dosen yang kurang memahami tata kerja penggunaan TIK dalampembelajaran daring.

\section{REFERENSI}

Badan Pusat Statistik. Indeks PembangunanManusia https://www.bps.go.id/publication/2021/04/3 0/8e777ce2d7570ced44197a37/indekspembangunan-manusia-2020.html.

Badan Pusat Statistik. Statistik Pendidikan 2020.Diakses pada https://bps.go.id/publication.html?Publikasi\% 5BtahunJudul\%5D=2020\&Publikasi\%5Bkata Kunci\%5D=pendidikan\&Publikasi\%5BcekJudul\%5D=0\&yt0=Tampilkan.

Adisel, Gawdy, A. P. (2020). Penggunaan Teknologi Informasi dan Komunikasi dalam Sistem Manajemen Pembelajaran pada masa Pandemi Covid 19. ALIGNMENT : Journal ofAdministration and Educational Management, 3(1), 1-10. https://journal.ipm2kpe.or.id/index.php/ALIG NMENT/article/view/1291

Damayanthi, A. (2020). Efektivitas Pembelajaran Daring di Masa Pandemi Covid 19 pada Perguruan Tinggi Keagamaan Katolik. JURNAL SOSIAL :Jurnal Penelitian Ilmu-Ilmu Sosial, 21(3), 53-56.http://sosial.unmermadiun.ac.id/index.php/sosi

al/article/view/61

Fetra Bonita Sari, Risda Amini, M. (2020). Jurnal basicedu. Jurnal Basicedu, 3(2), 524-532.

Fitriani, R. P. \& Y. (2020). Analisa Pemanfaatan Tehnologi Informasi Dalam Pembelajaran Jarak Jauh Di Tengah Pandemi Virus Corona Covid-19. Junal Of Information System, Applied, Management, ( Accounting and Researh). Vol, 4 No.2. Analisa Pemanfaatan Tehnologi Informasi Dalam Pembelajaran Jarak Jauh Di Tengah Pandemi Virus Corona Covid-19. Junal Of Information System, Applied, Management, ( Accounting and Researh). Vol, 4 No.2., 4(2), 30-36.

Hanifah Salsabila, U., Irna Sari, L., Haibati Lathif,K., Puji Lestari, A., \& Ayuning, A. (2020).Peran Teknologi Dalam Pembelajaran DiMasa Pandemi Covid-19. Al-Mutharahah:Jurnal Penelitian

$$
\text { Dan Kajian SosialKeagamaan, 17(2), 188-198. }
$$

https://doi.org/10.46781/al- mutharahah.v17i2.138

Keguruan, F., \& Sukabumi, U. M. (2020). Jurnalperseda. III(3), 176-181.

Surjono, H. D. (2010). Pemanfaatan Teknologi Informasi dan Komunikasi dalam Peningkatan Kualitas Pembelajaran,. Jakarta: Bumi Aksara., 2010.

Tekege, M. (2017). Pemanfaatan teknologi informasi dan komunikasi dalam pembelajaran SMA YPPGI Nabire. Jurnal Teknologi Dan Rekayasa, 2(1), 40-52. https://uswim.ejournal.id/fateksa/article/view/38 